\title{
Herbicide Detection in Groundwater in CóRRego Rico-SP WATERSHED ${ }^{1}$
}

\author{
Detecção de Herbicidas em Água Subterrânea na Microbacia do Córrego Rico-SP
}

\author{
SANTOS, E.A. ${ }^{2}$, CORREIA, N.M. ${ }^{3}$, SILVA, J.R.M. ${ }^{4}$, VELINI, E.D. ${ }^{4}$, PASSOS, A.B.R.J. ${ }^{5}$, and \\ DURIGAN, J.C. ${ }^{6}$
}

\begin{abstract}
Due to the large amount of pesticides applied in agriculture, mainly herbicides, there is a growing concern about a possible environmental contamination with these products, including water bodies. Given the above, the aim of the present work was to detect and quantify herbicides through multiresidue analysis in water samples collected in semiartesian wells and springs in a rural area of the city of Jaboticabal (SP). Samples were collected from 32 wells and 13 water springs, in three different seasons: October 2010, February 2011 and May 2011. Additionally, samples at a residence in the urban area were also collected. Analysis using high performance liquid chromatography coupled to mass spectrometry was performed and herbicides ametryn, amicarbazone, clomazone, diclosulan, diuron, hexazinone, imazapic, imazapyr, isoxaflutole, S-metolachlor, sulfentrazone, sulfometuron-methyl, and tebuthiuron were evaluated. In semi-artesian wells, an incresed quantity of herbicides was found in comparison with the water springs. Among the tested herbicides, hexazinone, imazapyr and sulfentrazone were detected in measurable amounts in accordance with the analytical method applied, while clomazone was the most common herbicide being detected in more than $60 \%$ of the samples. Ametryn, diuron and amicarbazone herbicides were also detected. Diclosulan, imazapic, isoxaflutole, S-metolachlor, sulfometuron-methyl, and tebuthiuron were not detected in any sample. Inappropriate use of these products without prior knowledge of the behavior of the soil can lead to groundwaters and water springs contamination, thus an ongoing monitoring of this resource becomes very important.
\end{abstract}

Keywords: sugarcane, LC-MS/MS, water springs, semi-artesian wells.

\begin{abstract}
RESUMO - Em vista da grande quantidade de agroquímicos aplicados na agricultura, principalmente os herbicidas, cresce a preocupação com a possivel contaminação do ambiente com esses produtos, inclusive em corpos d'água. Diante do exposto, o objetivo deste trabalho foi detectar e quantificar herbicidas, por meio de análise multirresíduo, em amostras de água coletadas em poços semiartesianos e nascentes, em uma área rural da cidade de Jaboticabal (SP). Foram coletadas amostras em 32 poços e 13 nascentes, em três épocas: outubro de 2010, fevereiro e maio de 2011. Foram coletadas, adicionalmente, amostras em uma residência na área urbana. Foi realizada análise por cromatografia liquida de alta eficiência acoplada à espectrometria de massas e foram avaliados os herbicidas ametryn, amicarbazone, clomazone, diclosulan, diuron, hexazinone, imazapic, imazapyr, isoxaflutole, S-metolachlor, sulfentrazone, sulfometuron-methyl e tebuthiuron. Em poços semiartesianos foram encontrados mais herbicidas em relação às nascentes. Entre os herbicidas avaliados, hexazinone, imazapyr e sulfentrazone foram detectados em valores quantificáveis de acordo com o método analitico, ao passo que o clomazone foi o herbicida mais frequente, sendo detectado em mais de $60 \%$ das amostras. Foram detectados também os herbicidas ametryn, amicarbazone e diuron. Em nenhuma das amostras foram detectados os herbicidas diclosulan, imazapic, isoxaflutole, S-metolachlor, sulfometuron-methyl e tebuthiuron. A utilização incorreta desses produtos, sem um prévio conhecimento do comportamento deles no solo, faz com que haja contaminação de águas subterrâneas e nascentes, tornando importante o monitoramento constante desse recurso.
\end{abstract}

Palavras-chave: cana-de-açúcar, LC-MS/MS, nascentes, poços semiartesianos.

Recebido para publicação em 4.11.2014 e aprovado em 25.11.2014.

Universidade Federal dos Vales do Jequitinhonha e Mucuri, Diamantina-MG, Brazil, <edsonapsant@yahoo.com.br>; ${ }^{3}$ Embrapa Hortaliças. Gama-DF, Brasil; ${ }^{4}$ Universidade Estadual Paulista “Júlio de Mesquita Filho", Botucatu-SP, Brazil; ${ }^{5}$ Universidade Federal de Viçosa, Viçosa-MG, Brasil; “ Universidade Estadual Paulista "Júlio de Mesquita Filho". Jaboticabal-SP, Brasil.

Planta Daninha, Viçosa-MG, v. 33, n. 1, p. 147-155, 2015 


\section{INTRODUCTION}

Phytosanitary products are related to modern agriculture and large productions. They are applied in fields with the purpose of controlling pests, diseases and weeds, preventing them from reducing the crop production potential. With an annual use of about 1 million tons, Brazil is currently the largest consumer of those products, among which herbicides are the most important, as they represent approximately 54\% of the volume (IBAMA, 2013).

Considering the huge amount of herbicides applied, once in the environment, these products may not reach the target, but contaminate surface and groundwater due to its ability to leach into the soil profile until attaining the water table and the well, however, in many cases, runoff occurs and the herbicide reaches and passes through the walls of the wells (Ritter, 1990). Once in this environment, water springs may also contain herbicides, because they are groundwater discharge points. It is noteworthy that these two water sources are commonly used for human consumption, especially in rural areas where there are no public wastewater sanitation services.

Depending on the physical and chemical characteristics, there is therefore the possibility of detection of this product in wells and water springs; Additionally, according to the water treatment system in cities, their detection is possible even in residential water samples (Lagana et al., 2002).

In a recent study on groundwater monitoring in 64 European countries, it was observed that herbicides are the most frequently detected phytosanitary products (Loos et al., 2010). In Brazil, after a four-year monitoring study, Gomes et al. (2006) found that the herbicide tebuthiuron was detected in semi-artesian wells with a depth of $53 \mathrm{~m}$, in Ribeirão Preto, Brazil. These authors relate the fact to the use of this product in cane sugar and to the physical characteristics of the soil in the watershed that was assessed.

Given the risk of detection in different environments, several studies evaluated the potential impacts of herbicides on human health. Richard et al. (2005) found that the enzyme aromatase, related to reproductive functions, is affected by glyphosate. Similarly, due to its detection at high levels in residential water, diuron was tested for its carcinogenic potential in mammals; in that research, Da Rocha et al. (2012) reported that the herbicide causes bladder cancer in mice when mixed in feed at a concentration of $2.500 \mathrm{ppm}$. Atrazine and its metabolites, another herbicide commonly found in groundwater and surface waters, cause endocrine disruption in male mice (Jin et al., 2014).

These studies supplant other works that seek to classify herbicides regarding the risk of water bodies contamination. Evaluations take into account characteristics related to herbicides and their use (Paraiba et al., 2003). Additionally, anchored in toxicology studies, human health protection and environmental agencies monitor water bodies and define the maximum allowable limits of those products in water (EPA, 2013; CANADA, 2013).

In Europe, the maximum allowable level of any herbicide in drinking water is $0.1 \mu \mathrm{g} \mathrm{L} \mathrm{L}^{-1}$, and the sum of contaminants shall not exceed $0.5 \mu \mathrm{g} \mathrm{L}^{-1}$ (European Union, 2013). However, despite its importance for of use of these products, Brazil does not have a drinking water national monitoring program to assess a potential contamination by them. Currently, only alachlor, atrazine, bentazon, 2,4-D, glyphosate, pendimethalin, propanil, simazine and trifluralin have statutory limits and standards for drinking water (IBGE, 2004).

Therefore, considering the large number of herbicides registered and used in agriculture and the importance of their detection in drinking water, this work aimed at detecting and quantifying herbicides in semi-artesian wells and water springs in rural areas, and in a residence in the urban area.

\section{MATERIALS AND METHODS}

Water samples collecting area comprised the city of Jaboticabal (SP), in the northern region of the state of São Paulo. Forty-six collection points were established, forty-five in the countryside and one in the city. The countryside is located within Córrego Rico watershed, at an altitude between 410 and 
740 meters, climate classified as Kwa (Koeppen); the main agricultural crop is sugarcane, and citrus, corn, vegetables, eucalyptus, coffee, cassava, banana and pineapple in smaller areas (Brasil, 2010). The predominant soil types are Oxisols and Ultisols Red-Yellow, with high sand content and low organic matter content (Arraes et al., 2010; Rodrigues et al., 2013).

Besides Jaboticabal, this watershed is part of the rural area of Monte Alto, Santa Ernestina, Guariba and Taquaritinga. In this area, there are dozens of homes and the drinking water used comes from semiartesian wells and water springs. In this sense, water samples were collected from 32 wells and 13 water springs. Three collections were carried out: from 28 to $30 / 11 / 2010$ (first season), from 05 to $08 / 02 / 2011$ (second season) and from 15 to 18/05/2011 (third season). The complete identification of collection points is presented in Table 1. During the collection period, precipitation patterns in the area were monitored (Table 2).

For the collection of water samples from wells, a suction pump was used and three simple samples (200 mL each) were placed in a stainless container, which generated a composite sample of $200 \mathrm{~mL}$. Likewise, in water springs, three simple samples were collected, which, after being mixed, generated a composite sample. These samples were collected at $1.0 \mathrm{~m}$ radius of the waterhole, and all of them were accommodated in amber flasks and transported in a polystyrene box containing ice, for storage at $-20^{\circ} \mathrm{C}$ until analysis.

Table 1 - Using geographic coordinates, identification (Id) of wells (P: depth in meters), water springs and the urban residence, where water samples were collected for multiresidue analysis of herbicides. Jaboticabal, SP

\begin{tabular}{|c|c|c|c|c|c|c|c|}
\hline \multirow{2}{*}{ Id } & \multicolumn{2}{|c|}{ Coordinates } & \multirow{2}{*}{$\mathrm{P}$} & \multirow{2}{*}{ Id. } & \multicolumn{2}{|c|}{ Coordinates } & \multirow{2}{*}{$\mathrm{P}$} \\
\hline & $S$ & $O$ & & & $S$ & $O$ & \\
\hline \multicolumn{8}{|c|}{ Semi-artesian wells } \\
\hline P1 & $21^{\circ} 16^{\prime} 36.88^{\prime \prime}$ & $48^{\circ} 21^{\prime} 10.46^{\prime \prime}$ & 20 & $\mathrm{P} 17$ & $21^{\circ} 15^{\prime} 31.66^{\prime \prime}$ & $48^{\circ} 23^{\prime} 57.95^{\prime \prime}$ & 130 \\
\hline $\mathrm{P} 2$ & $21^{\circ} 16^{\prime} 43.58^{\prime \prime}$ & $48^{\circ} 21^{\prime} 22.14^{\prime \prime}$ & 44 & $\mathrm{P} 18$ & $21^{\circ} 15^{\prime} 39.06^{\prime \prime}$ & $48^{\circ} 26^{\prime} 53.15^{\prime \prime}$ & 130 \\
\hline $\mathrm{P} 3$ & $21^{\circ} 17^{\prime} 42.25^{\prime \prime}$ & $48^{\circ} 21^{\prime} 56.09^{\prime \prime}$ & 40 & P19 & $21^{\circ} 16^{\prime} 41.26^{\prime \prime}$ & $48^{\circ} 25^{\prime} 56.01^{\prime \prime}$ & 150 \\
\hline $\mathrm{P} 4$ & $21^{\circ} 17^{\prime} 00.40^{\prime \prime}$ & $48^{\circ} 22^{\prime} 00.77^{\prime \prime}$ & 55 & $\mathrm{P} 20$ & $21^{\circ} 16^{\prime} 03.80^{\prime \prime}$ & $48^{\circ} 24^{\prime} 50.78^{\prime \prime}$ & 160 \\
\hline P5 & $21^{\circ} 16^{\prime} 51.49^{\prime \prime}$ & $48^{\circ} 22^{\prime} 08.94^{\prime \prime}$ & 110 & $\mathrm{P} 21$ & $21^{\circ} 16^{\prime} 33.32^{\prime \prime}$ & $48^{\circ} 24^{\prime} 55.85^{\prime \prime}$ & 150 \\
\hline P6 & $21^{\circ} 17^{\prime} 59.32^{\prime \prime}$ & $48^{\circ} 23^{\prime} 20.32^{\prime \prime}$ & 110 & $\mathrm{P} 22$ & $21^{\circ} 16^{\prime} 37.82^{\prime \prime}$ & $48^{\circ} 24^{\prime} 58.04^{\prime \prime}$ & 15 \\
\hline $\mathrm{P} 7$ & $21^{\circ} 18^{\prime} 51.32^{\prime \prime}$ & $48^{\circ} 24^{\prime} 33.04^{\prime \prime}$ & 150 & P23 & $21^{\circ} 16^{\prime} 44.66^{\prime \prime}$ & $48^{\circ} 24^{\prime} 57.86^{\prime \prime}$ & 300 \\
\hline P8 & $21^{\circ} 18^{\prime} 49.00^{\prime \prime}$ & $48^{\circ} 23^{\prime} 24.67^{\prime \prime}$ & 19 & $\mathrm{P} 24$ & $21^{\circ} 16^{\prime} 39.70^{\prime \prime}$ & $48^{\circ} 25^{\prime} 02.69^{\prime \prime}$ & 10 \\
\hline P9 & $21^{\circ} 17^{\prime} 51.20^{\prime \prime}$ & $48^{\circ} 25^{\prime} 54.49^{\prime \prime}$ & 90 & $\mathrm{P} 25$ & $21^{\circ} 17^{\prime} 22.07^{\prime \prime}$ & $48^{\circ} 26^{\prime} 08.09^{\prime \prime}$ & 68 \\
\hline P10 & $21^{\circ} 17^{\prime} 57.35^{\prime \prime}$ & $48^{\circ} 26^{\prime} 37.12^{\prime \prime}$ & 120 & P26 & $21^{\circ} 18^{\prime} 36.26^{\prime \prime}$ & $48^{\circ} 25^{\prime} 17.91^{\prime \prime}$ & 8 \\
\hline P11 & $21^{\circ} 16^{\prime} 56.19^{\prime \prime}$ & $48^{\circ} 25^{\prime} 23.70^{\prime \prime}$ & 150 & P27 & $21^{\circ} 17^{\prime} 42.71^{\prime \prime}$ & $48^{\circ} 25^{\prime} 29.09^{\prime \prime}$ & 10 \\
\hline $\mathrm{P} 12$ & $21^{\circ} 16^{\prime} 59.54^{\prime \prime}$ & $48^{\circ} 25^{\prime} 22.64^{\prime \prime}$ & 110 & $\mathrm{P} 28$ & $21^{\circ} 19^{\prime} 12.84^{\prime \prime}$ & $48^{\circ} 24^{\prime} 12.63^{\prime \prime}$ & 110 \\
\hline $\mathrm{P} 13$ & $21^{\circ} 17^{\prime} 18.39^{\prime \prime}$ & $48^{\circ} 21^{\prime} 57.23^{\prime \prime}$ & 120 & P29 & $21^{\circ} 19^{\prime} 12.84^{\prime \prime}$ & $48^{\circ} 24^{\prime} 12.63^{\prime \prime}$ & 110 \\
\hline P14 & $21^{\circ} 17^{\prime} 36.18^{\prime \prime}$ & $48^{\circ} 23^{\prime} 05.80^{\prime \prime}$ & 120 & $\mathrm{P} 30$ & $21^{\circ} 19^{\prime} 12.84^{\prime \prime}$ & $48^{\circ} 24^{\prime} 12.63^{\prime \prime}$ & 110 \\
\hline $\mathrm{P} 15$ & $21^{\circ} 16^{\prime} 19.55^{\prime \prime}$ & $48^{\circ} 23^{\prime} 06.84^{\prime \prime}$ & 45 & P31 & $21^{\circ} 18^{\prime} 53.73^{\prime \prime}$ & $48^{\circ} 24^{\prime} 04.40^{\prime \prime}$ & 35 \\
\hline P16 & $21^{\circ} 16^{\prime} 24.49^{\prime \prime}$ & $48^{\circ} 23^{\prime} 48.53^{\prime \prime}$ & 120 & $\mathrm{P} 32$ & $21^{\circ} 18^{\prime} 44.57^{\prime \prime}$ & $48^{\circ} 23^{\prime} 25.94^{\prime \prime}$ & 20 \\
\hline \multicolumn{8}{|c|}{ Water springs } \\
\hline N1 & $21^{\circ} 18^{\prime} 51.32^{\prime \prime}$ & $48^{\circ} 24^{\prime} 38.13^{\prime \prime}$ & - & $\mathrm{N} 8$ & $21^{\circ} 16^{\prime} 08.47^{\prime \prime}$ & $48^{\circ} 24^{\prime} 49.61^{\prime \prime}$ & - \\
\hline N2 & $21^{\circ} 17^{\prime} 45.88^{\prime \prime}$ & $48^{\circ} 25^{\prime} 12.71^{\prime \prime}$ & - & N9 & $21^{\circ} 16^{\prime} 43.57^{\prime \prime}$ & $48^{\circ} 25^{\prime} 08.62^{\prime \prime}$ & - \\
\hline N3 & $2118^{\prime} 46.31 "$ & $48^{\circ} 23^{\prime} 24.63^{\prime \prime}$ & - & N10 & $21^{\circ} 17^{\prime} 22.25^{\prime \prime}$ & $48^{\circ} 26^{\prime} 09.01^{\prime \prime}$ & - \\
\hline N4 & $21^{\circ} 17^{\prime} 12.47^{\prime \prime}$ & $48^{\circ} 25^{\prime} 35.26^{\prime \prime}$ & - & N11 & $21^{\circ} 18^{\prime} 05.02^{\prime \prime}$ & $48^{\circ} 22^{\prime} 38.87^{\prime \prime}$ & - \\
\hline N5 & $21^{\circ} 17^{\prime} 26.65^{\prime \prime}$ & $48^{\circ} 23^{\prime} 13.30^{\prime \prime}$ & - & N12 & $21^{\circ} 17^{\prime} 42.71^{\prime \prime}$ & $48^{\circ} 25^{\prime} 29.09^{\prime \prime}$ & - \\
\hline N6 & $21^{\circ} 16^{\prime} 15.02^{\prime \prime}$ & $48^{\circ} 23^{\prime} 04.32^{\prime \prime}$ & - & N13 & $21^{\circ} 18^{\prime} 42.14^{\prime \prime}$ & $48^{\circ} 23^{\prime} 26.63^{\prime \prime}$ & - \\
\hline N7 & $21^{\circ} 16^{\prime} 16.77^{\prime \prime}$ & $48^{\circ} 23^{\prime} 35.01^{\prime \prime}$ & - & & & & \\
\hline \multicolumn{8}{|c|}{ Urban residence } \\
\hline R1 & $21^{\circ} 14^{\prime} 35.30^{\prime \prime}$ & $48^{\circ} 18^{\prime} 40.66^{\prime \prime}$ & - & & & & \\
\hline
\end{tabular}


In the laboratory, samples were shaken and $2.0 \mathrm{~mL}$ were filtered $(0.45 \mu \mathrm{m}$ filter and $13 \mathrm{~mm}$ membrane filter). Finally, they were placed in amber glass vial $(9.0 \mathrm{~mm})$ for high efficiency liquid chromatography in combination with mass spectrometry (LC-MS/MS) analysis.

In the High Performance Liquid Chromatograph (Shimadzu/Proeminence UFLC), C18 column was used. The chromatographic conditions were as follows: a mobile phase consisting of a mixture of methanol and water, with $0.5 \%$ acetic acid, in gradient mode; flow rate of $0.4 \mathrm{~mL}$ per minute and $30 \mathrm{uL}$ injection. The total running time was 19 minutes.

In the hybrid triple quadrupole mass spectrometer (3200 QTRAP/Applied Biosystems) the creation of the three charged ions (fragments) takes place, which, as a function of herbicide mass/charge relation (Table 3), enables the detector to count the electrons generated.

Table 2 - Monthly accumulated rainfall in the rural area were samples were collected for herbicide detection. Collecting dates: D1: from 28 to 30/11/2010, D2: from 05 to 08/02/2011 and D3: from 15 to 18/05/2011. Jaboticabal, SP

\begin{tabular}{|c|c|c|c|c|c|c|c|}
\hline \multirow{2}{*}{ Analyte } & \multirow{2}{*}{$\mathrm{TR}$} & \multirow{2}{*}{ Linearity equation } & \multirow{2}{*}{$\mathrm{CC}$} & \multicolumn{4}{|c|}{ Molecular weight $\left(\mathrm{g} \mathrm{mol}^{-1}\right)$} \\
\hline & & & & AP & IS1 & IS2 & IS3 \\
\hline Ametryn & 8.53 & $\mathrm{y}=20700 \mathrm{x}-2880$ & 99.5 & 228.13 & 186.1 & 68.1 & 96.2 \\
\hline Amicarbazone & 7.85 & $\mathrm{y}=15900 \mathrm{x}-9610$ & 99.3 & 505.31 & 165.3 & 264.2 & 183.3 \\
\hline Clomazone & 9.12 & $\mathrm{y}=11200 \mathrm{x}+3810$ & 99.4 & 240.20 & 125.1 & 89.1 & 99.1 \\
\hline Diclosulan & 8.13 & $y=4040 x+176$ & 99.5 & 405.94 & 160.9 & 90.2 & 125.1 \\
\hline Diuron & 8.98 & $y=191 x+158$ & 99.2 & 234.03 & 72.0 & 73.1 & 174.0 \\
\hline Hexazinone & 8.28 & $y=12100 x-411$ & 99.6 & 253.30 & 171.2 & 71.2 & 85.2 \\
\hline Imazapic & 6.96 & $\mathrm{y}=1690 x-530$ & 95.2 & 276.14 & 163.2 & 69.1 & 86.1 \\
\hline Imazapyr & 6.18 & $y=810 x-57.5$ & 99.6 & 262.12 & 78.2 & 69.2 & 86.2 \\
\hline Isoxaflutole & 8.53 & $\mathrm{y}=5990 \mathrm{x}+849$ & 99.5 & 360.05 & 251.2 & 220.2 & 144 \\
\hline S-metolachlor & 9.77 & $y=10100 x+3010$ & 99.7 & 284.21 & 252.3 & 176.2 & 91.1 \\
\hline Sulfentrazone & 8.02 & $\mathrm{y}=1250 \mathrm{x}+2000$ & 99.2 & 386.95 & 110.2 & 146.1 & 273.1 \\
\hline Sulfometuron-methyl & 7.85 & $\mathrm{y}=3800 \mathrm{x}-111$ & 99.6 & 365.08 & 150.2 & 107.1 & 67.2 \\
\hline Tebuthiuron & 8.25 & $\mathrm{y}=10500 \mathrm{x}-959$ & 99.0 & 229.25 & 172.3 & 116.1 & 62.0 \\
\hline
\end{tabular}

Table 3 - Parameters related to the quantification of herbicides using LC-MS/MS. TR: retention time (minutes), CC: equation correlation coefficient (\%), AP: main analyte, IS: secondary ion. Jaboticabal, SP

\begin{tabular}{|c|c|c|c|c|c|c|c|}
\hline \multirow{2}{*}{ Analyte } & \multirow{2}{*}{$\mathrm{TR}$} & \multirow{2}{*}{ Linearity equation } & \multirow{2}{*}{$\mathrm{CC}$} & \multicolumn{4}{|c|}{ Molecular weight $\left(\mathrm{g} \mathrm{mol}^{-1}\right)$} \\
\hline & & & & AP & IS1 & IS2 & IS3 \\
\hline Ametryn & 8.53 & $y=20700 x-2880$ & 99.5 & 228.13 & 186.1 & 68.1 & 96.2 \\
\hline Amicarbazone & 7.85 & $y=15900 x-9610$ & 99.3 & 505.31 & 165.3 & 264.2 & 183.3 \\
\hline Clomazone & 9.12 & $y=11200 x+3810$ & 99.4 & 240.20 & 125.1 & 89.1 & 99.1 \\
\hline Diclosulan & 8.13 & $y=4040 x+176$ & 99.5 & 405.94 & 160.9 & 90.2 & 125.1 \\
\hline Diuron & 8.98 & $y=191 x+158$ & 99.2 & 234.03 & 72.0 & 73.1 & 174.0 \\
\hline Hexazinone & 8.28 & $y=12100 x-411$ & 99.6 & 253.30 & 171.2 & 71.2 & 85.2 \\
\hline Imazapic & 6.96 & $y=1690 x-530$ & 95.2 & 276.14 & 163.2 & 69.1 & 86.1 \\
\hline Imazapyr & 6.18 & $y=810 x-57.5$ & 99.6 & 262.12 & 78.2 & 69.2 & 86.2 \\
\hline Isoxaflutole & 8.53 & $y=5990 x+849$ & 99.5 & 360.05 & 251.2 & 220.2 & 144.0 \\
\hline S-metolachlor & 9.77 & $\mathrm{y}=10100 \mathrm{x}+3010$ & 99.7 & 284.21 & 252.3 & 176.2 & 91.1 \\
\hline Sulfentrazone & 8.02 & $y=1250 x+2000$ & 99.2 & 386.95 & 110.2 & 146.1 & 273.1 \\
\hline Sulfometuron-methyl & 7.85 & $\mathrm{y}=3800 \mathrm{x}-111$ & 99.6 & 365.08 & 150.2 & 107.1 & 67.2 \\
\hline Tebuthiuron & 8.25 & $y=10500 x-959$ & 99.0 & 229.25 & 172.3 & 116.1 & 62.0 \\
\hline
\end{tabular}


Using this method, it was possible to detect 13 herbicides with detection limits (LOD) and quantification limits (LOQ) of 0.95 and $3.13 \mu \mathrm{g} \mathrm{L}^{-1}$ for diuron and 0.12 and $0.391 \mu \mathrm{g} \mathrm{L} \mathrm{L}^{-1}$ for other herbicides, respectively, determined by the signal/noise ratio (Ribani et al., 2004). Parameters for detection are shown in Table 3.

Data were qualitatively evaluated through frequency of occurrence and higher concentration detected.

\section{RESULTS AND DISCUSSION}

In general, in terms of frequency of herbicide detection, it was observed that samples collected between December 2010 and May 2011 have more residues compared to samples obtained in February 2010. In $88.9 \%$ of the samples collected in the first and second season, there is at least one herbicide, whereas in samples taken in the second season the value is $80 \%$.

A greater volume of accumulated precipitation was observed in February 2011 in comparison with other periods. This larger volume of water in the system is likely to have contributed to the dilution of herbicides and consequently to a reduced detection. It is worth emphasizing that, during the months of October and November, herbicides applications and soil preparation take place in this area. In May, herbicide applications for weed management after sugarcane harvest are performed, however, during the period of heavy rainfalls (February), operations in these areas almost do not occur.

Regarding the collecting matrix, no herbicide residues were detected in the sample from the urban area. In the city of Jaboticabal, $70 \%$ of public water supply comes from Córrego Rico watershed, and the water is distributed after treatment. It is likely that water treatment is responsible for the removal of pesticides residues, but a greater number of samples would be necessary. On the other hand, qualitative parameters related to herbicide detection semi-artesian wells are most prominent in relation to the water springs (Table 4).

In the study area, soil preparation for sugarcane, citrus, corn, peanut, guava, and other crops occur periodically. A good part of the detected herbicides has long-lasting residual effects; thus, once in the soil, rainfalls promote the transportation of the product into groundwater (Paraiba et al., 2003). It is noteworthy that most of the water springs assessed were protected by woods and located in remote areas far from crops or at the top of the slopes, factors that hinder the entry of phytosanitary products in water (Rasmussen et al., 2011).

Another factor that may be related to herbicide detection of in semi-artesian wells is related to their purpose. Some are used for mixing, washing of equipment and herbicides packaging. For this reason, it is likely that herbicide residues, detected in some of them, have reached the bottom of the wells by runoff or infiltration in their walls. This fact also justifies the highest contamination rates in times of increased use of herbicides.

There was no relationship between the detected herbicides or their residues and the depth of the wells. Products were detected in shallower and greater depths, a fact that relates contamination with products usage characteristics or factors related to the soil profile.

Once in solution, herbicides can leach to deeper layers, where microbial activity is reduced or insignificant. The absence of plant roots, the lack of temperature variation and the maintenance of physical and chemical characteristics in a constant level enables the herbicide molecule to keep its original form, facilitating its transport into the groundwater (Paraiba et al., 2003; Morgante et al., 2012).

In the study area, there is a current interest in assessing pesticide contamination of groundwater, since it is on the Guarani Aquifer, the main fresh water reserve in South America (Rabelo \& Wendland, 2009). In recent studies, results on the herbicide contamination of aquifer waters are presented, and several authors highlight the necessity to monitor products in order to protect the water spring (Gomes et al., 2006; Queiroz et al., 2009).

In drinking water, none of the tested herbicides has a maximum level established 
Table 4 - Herbicide frequency (\%) and largest residue $(\mu \mathrm{g} \mathrm{L}-1)$ in water samples collected from wells $(\mathrm{Po})$ and water springs $(\mathrm{Na})$, in three seasons, and analyzed using LC-MS/MS. Jaboticabal (SP)

\begin{tabular}{|c|c|c|c|c|c|c|c|c|c|c|c|}
\hline \multirow{3}{*}{ Herbicide } & \multicolumn{2}{|c|}{ Frequency } & \multicolumn{2}{|c|}{ Largest residue } & \multicolumn{2}{|c|}{ Frequency } & $\begin{array}{l}\text { Largest } \\
\text { residue }\end{array}$ & \multicolumn{2}{|c|}{ Frequency } & \multicolumn{2}{|c|}{ Largest residue } \\
\hline & \multicolumn{4}{|c|}{28 to $30 / 11 / 2010$} & \multicolumn{3}{|c|}{05 to $08 / 02 / 2011$} & \multicolumn{4}{|c|}{15 to $18 / 05 / 201$} \\
\hline & Po & $\mathrm{Na}$ & Po & $\mathrm{Na}$ & Po & $\mathrm{Na}$ & Po & Po & $\mathrm{Na}$ & Po & $\mathrm{Na}$ \\
\hline Ametryn & 3.1 & - & $<$ LOQ & - & & & & 3.1 & 7.7 & $<$ LOQ & - \\
\hline Amicarbazone & & & & & & & & 12.5 & - & $<$ LOQ & - \\
\hline Clomazone & 71.9 & 61.5 & $<\mathrm{LOQ}$ & $<\mathrm{LOQ}$ & 62.5 & & $<\mathrm{LOQ}$ & 56.3 & 69.2 & $<\mathrm{LOQ}$ & $<\mathrm{LOQ}$ \\
\hline Diuron & 9.4 & 15.4 & $<\mathrm{LOQ}$ & $<\mathrm{LOQ}$ & 12.5 & & $<$ LOQ & 18.8 & - & $<\mathrm{LOQ}$ & - \\
\hline Hexazinone & & & & & & & & 18.8 & - & 0.718 & - \\
\hline Imazapyr & 6.3 & - & $<$ LOQ & - & 3.1 & & 0.403 & - & 7.7 & - & 0.553 \\
\hline Sulfentrazone & 21.9 & 15.4 & 0.606 & 0.640 & 34.4 & 15.4 & 0.521 & 31.3 & 30.8 & 0.413 & $<\mathrm{LOQ}$ \\
\hline
\end{tabular}

by Brazilian law (IBGE, 2004). Thus, considering the precautionary principle adopted by the European Community, it is observed that $17 \%$ of all samples have at least one herbicide with residual above $0.1 \mu \mathrm{g} \mathrm{L} \mathrm{L}^{-1}$. Note that these tests may not be definitive, since there may be other pesticides in water samples, due to the large number of active ingredients registered for use in the study area (Brasil, 2013).

With respect to legislation on the intake of herbicide residue through water, there are no international standards establishing the maximum allowable limits. The limit is frequently imposed according to the analytical method, taking into account the minimum residue detected. On the other hand, with a view on food trade between countries and health protection, the World Health Organisation (WHO, 2013) sets the recommended maximum intake of products present in foods.

The limits are anchored in several toxicological tests, with the participation of more than 160 countries through Codex Alimentarius. In the present work, considering the highest rate of herbicide residue detected (2.65 $\mathrm{mg} \mathrm{L}^{-1}$ at P23 point) and the ingestion of two liters of water per day, the annual herbicide per capita consumption would be close to $1.93 \mathrm{mg}$. This is an insignificant value when compared to the limits established by the international code (WHO, 2013).

Regarding herbicides, among the 13 products assessed, diclosulan, imazapic, isoxaflutole, S-metalochlor, sulfometuron- methyl and tebuthiuron were not detected in any sample. Despite the fact that all these herbicides are used in sugarcane, the predominant crop in the study area, it is likely that the reduced use of the products is the most relevant factor related to non-detection.

When assessing quantitatively the herbicide contamination, hexazinone, imazapyr and sulfentrazone were the only products detected at concentrations above the limit of quantification of the analytical method (Table 4). In wells, the maximum depths in which those products were identified were: 150, 130 and $160 \mathrm{~m}$, respectively.

These three herbicides have been used together very often in weed management in sugarcane crops due of its efficiency in the control of important species such as convolvulaceae and cyperaceae (Rodrigues \& Almeida, 2011). Additionally, the most influential characteristics in the products leaching potential are solubility and adsorption to soil particles (Larsbo et al., 2009).

Hexazinone and imazapyr have the highest solubility values among products evaluated (Garcia et al., 2012; Gianelli et al., 2014), while sulfentrazone is extremely persistent in soil and has a low adsorption coefficient (Passos et al., 2013). Jointly, according to Gustafson (1989) and Laskowski et al. (1982), these features help to classify these products as the most probably detected in groundwater (Table 5).

The rate proposed (and widely adopted) by Gustafson (1989) arranges herbicide 
characteristics such as the coefficient of adsorption to soil organic carbon (Koc) and the half-life $\left(\mathrm{t}_{1 / 2}\right)$, so GUS values lower or equal to 1.8 indicate a nonleachable herbicide, values ranging from 1.8 to 2.8 compose a transition zone; and values above 2.8 classify products as leachable. As a complement, LEACH index also describes the possibility of surface water contamination; it is calculated using Koc, $\mathrm{t}_{1 / 2}$, the water solubility rate and the products vapor pressure. For evaluation, the higher the $\mathrm{LEACH}$, the higher the likelihood of leaching.

Qualitatively, clomazone herbicide may be considered the most important contaminant. In over $60 \%$ of water samples was the herbicide detected in all collecting seasons (Table 4) and at depths up to $160 \mathrm{~m}$. This herbicide has been used for striking weed management in the current sugarcane cultivation system, mainly due to its efficacy (Carbonari et al., 2010). According to Santos et al. (2013), clomazone has a high groundwater contamination potential, because of its high solubility in water $\left(1.1 \mathrm{~L}^{-1}\right)$ and a Koc of $300 \mathrm{~mL} \mathrm{~g}^{-1}$.

Diuron herbicide (detected at $300 \mathrm{~m}$ of depth) can also be considered one of the most important in terms of frequency. Despite its low solubility in water, high adsorption to soil colloids which can be related to organic matter content, this herbicide display a high resilience level, as it has a half-life greater than one year (Table 5). It is important to note that, in this area, the product is also used in mixtures during water shortage periods; in this situation, microbial activity is limited, and the physicochemical characteristics of the soil in the study area (Arraes et al., 2010; Rodrigues et al., 2013) allow the movement of the herbicide and its detection at different depths.

S-metolachlor herbicide also stood out in the analysis, especially in the first collecting season (Table 4), which was detected at a depth of $160 \mathrm{~m}$. Its physicochemical characteristics do not qualify it as one of the major groundwater pollutants (Table 5); thus its outstanding frequency of occurrence may be related to the use, since the product is extensively used in corn and sugarcane crops, and the low organic matter content in the study area favors and increases its movement in the soil (Procopio et al., 2001).
Ametryn is also amongst herbicides detected in wells and water springs in Córrego Rico watershed (Table 4), at a maximum depth of $110 \mathrm{~m}$. On its turn, amicarbazone was detected in four water samples from wells collected in May 2011. The maximum detection depth of this herbicide was $120 \mathrm{~m}$.

These four products are registered for a combined use together in sugarcane, citrus, corn, pastures, eucalyptus, coffee, potatoes, cassava, banana and pineapple crops, all of them cultivated in the study area. However, the only crop for which all herbicides are registered is the sugarcane one (Brasil, 2013), that also occupies more than $80 \%$ of the study area (Rodrigues et al., 2013).

Therefore, agricultural practices for weed management in the study area, along with soil and climatic characteristics of the region, are factors related to losses of the pesticides applied and a subsequent detection in underground water bodies. This information provides adequate support a decision-making process on herbicide application techniques, dosages and active ingredients used as well as on the risks of drinking water contamination.

It is concluded that the samples collected in semi-artesian wells have quantifiable residues of the following herbicides: hexazinone, imazapyr and sulfentrazone. The last two were also quantified in samples collected in water springs. Ametryn,

Table 5 - Physico-chemical characteristics of detected herbicides in water samples from wells and water springs in Córrego Rico watershed, Jaboticabal, SP

\begin{tabular}{|l|r|r|r|r|r|}
\hline \multicolumn{1}{|c|}{ Herbicide } & Half-life $^{1 /}$ & $\mathrm{Koc}^{2 /}$ & $\mathrm{SA}^{\frac{3 /}{}}$ & $\mathrm{GUS}^{4 /}$ & $\mathrm{Le}^{5 /}$ \\
\hline Ametryn & 53 & 300 & 200 & 5.98 & 6.9 \\
\hline Amicarbazone & 150 & 30 & 4600 & 3.34 & $\mathrm{Nd}$ \\
\hline Clomazone & 24 & 150 & 1100 & 2.1 & 3.7 \\
\hline Diclosulan & 75 & 90 & 6.3 & 3.46 & $\mathrm{Nd}$ \\
\hline Diuron & 372 & 480 & 42 & 3.38 & 6.5 \\
\hline Hexazinone & 222 & 54 & 33000 & 2.8 & 9.5 \\
\hline Imazapyr & 90 & 100 & 11300 & 3.90 & $\mathrm{Nd}$ \\
\hline Isoxaflutole & 18 & 134 & 6.2 & 0.59 & $\mathrm{Nd}$ \\
\hline S-metolachlor & 33 & 200 & 488 & 1.94 & $\mathrm{Nd}$ \\
\hline Sulfentrazone & 548 & 43 & 490 & 6.48 & 10.9 \\
\hline Tebuthiuron & 1220 & 80 & 2500 & 6.31 & 8.1 \\
\hline
\end{tabular}


amicarbazone, clomazone and diuron were also detected in samples from both locations, but not in quantifiable levels.

Finally, diclosulan, imazapic, isoxaflutole, S-metalochlor, sulfometuron-methyl and tebuthiuron were not detected in any water sample.

Improper use of these products without prior knowledge of their behavior of the soil can lead to groundwater and water springs contamination, thus an ongoing monitoring of this resource becomes very important.

\section{LITERATURE CITED}

ARRAES, C. L. et al. Morfometria dos Compartimentos Hidrológicos do Município de Jaboticabal, SP. Unopar Cient. Ci. Exatas Tecnol., v. 9, n. 1, p. 27-32, 2010.

BRASIL - Ministério da Saúde. Portaria n518/GM, 25 de março de 2004. Padrão de potabilidade para substâncias químicas que representam risco à saúde. Disponível em: $<$ http://dtr2001.saude.gov.br/sas/PORTARIAS/Port2004/ GM/GM-518.htm>. Acesso em: 15 jul. 2013.

INSTITUTO BRASILEIRO DE GEOGRAFIA E ESTATÍSTICA - IBGE. Lavoura temporária, São Paulo: 2010. Disponível em: <http://www.ibge.gov.br/cidadesat/ xtras/uf.php? coduf $=35 \&$ search $=$ sao-paulo $>$. Acesso em: 12 jul. 2013.

BRASIL: Ministério da Agricultura, Pecuária e Abastecimento. AGROFIT - Sistema de Agrotóxicos Fitossanitários, 2013. Disponível em: <http:// extranet.agricultura.gov.br/agrofit_cons/ principal_agrofit_cons>. Acesso em: 20 jul. 2013.

CANADA. Pest Management Regulatory Agency- Health Canada. Estimating the water component of a dietary exposure assessment (SPN2004-01). Disponível em: <http:/ /www.hc-sc.gc.ca/cps-spc/alt_formats/pacrb-dgapcr/pdf/pubs/ pest/pol-guide/spn/spn2004-01-eng.pdf $>$. Acesso em: 15 jul. 2013.

CARBONARI, C. A. et al. Eficácia da associação entre os herbicidas clomazone e hexazinona no controle de plantas daninhas em cana-de-açúcar. R. Bras. Herbic., v. 9, n. 1, p. $17-25,2010$.

DA ROCHA, M. S. et al. Diuron-induced rat bladder epithelial cytotoxicity. Toxicol. Sci., v. 130, n. 2, p. 281-288, 2012.

UNITED STATES ENVIRONMENTAL PROTECTION AGENCY - EPA. National Primary Drinking Water Regulations (EPA 816-F-09-0004, May 2009). Disponível em: $<$ http://water.epa.gov/drink/contaminants/upload/mcl2.pdf $>$. Acesso em: 15 jul. 2013.
GARCIA, D. B. et al. Lixiviação de diuron, hexazinone e sulfometuron-methyl em formulação comercial e isoladamente em dois solos contrastantes. R. Bras. Herbic., v. 11, n. 2, p. 222-230, 2012.

GIANELLI, V. R.; BEDMAR, F.; COSTA, J. L. Persistence and sorption of imazapyr in three argentinean soils. Environ. Toxicol. Chem., v. 33, n. 1, p. 29-34, 2014.

GOMES, M. A. F. et al. Movimento do herbicida tebutiuron em dois solos representativos das áreas de recarga do aqüífero Guarani. R. Bras. Eng. Agríc. Amb., v. 10, n. 2, p. 479-483, 2006.

GUSTAFSON, D. I. Groundwater ubiquity scores: a simple method for assessing pesticide leachability. Environ. Toxicol. Chem., v. 8, n. 4, p. 339-357, 1989.

INSTITUTO BRASILEIRO DO MEIO AMBIENTE E DOS RECURSOS NATURAIS RENOVÁVEIS - IBAMA.

Boletim Anual sobre Produção, Importação, Exportação e Vendas de Produtos Agrotóxicos no Brasil - 2013.

Disponível em: $<$ http://www.ibama.gov.br/areas-tematicas-qa/ relatorios-de-comercializacao-de-agrotoxicos/pagina-3>.

Acesso em: 12 nov. 2014.

JIN, Y. et al. Exposure of mice to atrazine and its metabolite diaminochlorotriazine elicits oxidative stress and endocrine disruption. Environ. Toxicol. Pharmacol., v. 37, n. 2, p. 782-790, 2014.

LAGANA, A. et al. Occurrence and determination of herbicides and their major transformation products in environmental waters. Anal. Chim. Acta, v. 462, n. 2, p. $187-$ 198, 2002.

LARSBO, M. Herbicide sorption, degradation, and leaching in three Swedish soils under long-term conventional and reduced tillage. Soil Tillage Res., v. 105, n. 2, p. 200-208, 2009.

LASKOWSKI, D. A. et al. Terrestrial environment. In: CONWAY, R. A. (Ed.). Environmental risk analysis for chemicals. New York: Van Nostrand Reinhold, 1982. p. $198-240$.

LOOS, R. et al. Pan-European survey on the occurrence of selected polar organic persistent pollutants in ground water. Water Res., v. 44, n. 14, p. 4115-4126, 2010.

MORGANTE, V. et al. Influence of microorganisms and leaching on simazine attenuation in an agricultural soil. J. Environ. Manag., v. 95, p. S300-S305, 2012.

PARAÍBA, L. C. et al. Evaluation of soil temperature effect on herbicide leaching potential into groundwater in the Brazilian Cerrado. Chemosphere, v. 53, n. 9, p. 1087-1095, 2003. 
PASSOS, A. B. R. J. et al. Sorption and desorption of sulfentrazone in Brazilian soils. J. Environ. Sci. Health, Part B: Pestic. Food Contam. Agric. Wastes, v. 48, n. 8, p. 646-650, 2013.

PROCÓPIO, S. D. et al. Efeito da irrigação inicial na profundidade de lixiviação do herbicida S-metolachlor em diferentes tipos de solo. Planta Daninha, v. 19, n. 3, p. 409-417, 2001.

QUEIROZ, S. C. N. et al. Comportamento do herbicida hexazinone em área de recarga do aqüífero Guarani cultivada com cana-de-açúcar. Química Nova, v. 32, n. 2, p. 378-381, 2009.

RABELO, J. L.; WENDLAND, E. Assessment of groundwater recharge and water fluxes of the Guarani Aquifer System, Brazil. Hydrogeol. J., v. 17, n. 7, p. 1733-1748, 2009.

RASMUSSEN, J. J. et al. Buffer strip width and agricultural pesticide contamination in Danish lowland streams: Implications for stream and riparian management. Ecol. Eng., v. 37, n. 12, p. 1999-1997, 2011.

RIBANI, M. et al. Validation for chromatographic and electrophoretic methods. Química Nova, v. 27, n. 5, p. 771-780, 2004.

RICHARD, S. et al. Differential effects of glyphosate and roundup on human placental cells and aromatase. Environ. Health Persp., v. 113, n. 6, p. 716-720, 2005.
RITTER, W. F. Pesticide contamination of ground water in the United States. A review. J. Environ. Sci. Health, Part B: Pestic. Food Contam. Agric. Wastes, v. 25, n. 1, p. 1-29, 1990.

RODRIGUES, B. N.; ALMEIDA, F. S. Guia de herbicidas. 6.ed. Londrina: Edição dos Autores, 2011. $697 \mathrm{p}$.

RODRIGUES, M. F. et al. Mapping for environmental planning the basin of Córrego Rico, São Paulo. J. Hypersp. Remote Sens., v. 3, n. 3, p. 45-58, 2013.

SANTOS, E. A.; CORREIA, N. M.; BOTELHO, R. G. Resíduos de herbicidas em corpos hídricos - uma revisão. R. Bras. Herbic., v. 12, n. 2, p. 188-201, 2013.

UNIÃO EUROPÉIA - EU. Jornal Oficial da Comunidade Européia. Diretiva 98/83/CE de 5/12/1998. Conselho da União Europeia. Qualidade da Água Para Consumo Humano. Bruxelas: 1998. Disponível em: <http://eur-lex.europa.eu/ LexUriServ/LexUriServ.do?uri=OJ:L:1998:330:0032:0054:PT: PDF>. Acesso em: 17 jul. 2013.

WORLD HEALTH ORGANIZATION - WHO. International Food Standards/Codex Alimentarius Commission. Disponível em: $<\mathrm{http}: / /$ www.codexalimentarius.org/standards/pesticide-mrls/en/>. Acesso em: 17 jul. 2013. 